\title{
OPTIMALISASI PEMBELAJARAN JARAK JAUH DENGAN MEMANFAATKAN SARANA TEKNOLOGI INFORMASI DAN KOMUNIKASI
}

\author{
Reksa Adya Pribadi ${ }^{1}$, Adhinda Rafelliya S.P ${ }^{2}$, Evania Dini Rahmayanti ${ }^{3}$ \\ ${ }^{123}$ PGSD Fakultas Keguruan dan IImu Pendidikan, Universitas Sultan Ageng \\ Tirtayasa
}

reksapribadi@untirta.ac.id, 2227190054@untirta.ac.id, 2227190058@untirta.ac.id

\begin{abstract}
This research has a problem formulation, namely how to optimize distance learning with information and communication technology. The purpose of this research is to find out how the process of optimizing distance learning with information and communication technology. This research uses an approach approach, descriptive method. Qualitative research is presented descriptively. The subjects of this study were class III B teachers and class III B students at SDN Cikokol 1 Tangerang City. The object of this research is the process of optimizing distance learning with information and communication technology. Data collection techniques using interview and observation techniques. The results of this study indicate that in the distance learning process students are enthusiastic about participating in the learning process using information and communication technology. This can be seen from their activeness when carrying out distance learning. Students are also easier to catch and understand the subject matter so that students are more interested and more focused in learning. To optimize information and communication technology in distance learning is not yet fully optimal, because of this distance learning process, it becomes difficult for teachers to measure the level of student understanding, student character and assessment during their academic years. Even safe, this distance learning process is only $80 \%$ of students who can access the video conferencing used.
\end{abstract}

Keywords: Optimal, Distance Learning, Technology, Information, Communication

\begin{abstract}
ABSTRAK
Penelitian ini memiliki rumusan masalah yaitu bagaimana mengoptimalisasi pembelajaran jarak jauh dengan teknologi informasi dan komunikasi. Tujuan dari penelitian ini adalah untuk mengetahui bagaimana proses mengoptimalisasi pembelajaran jarak jauh dengan teknologi informasi dan komunikasi. Penelitian ini menggunakan pendekatan kualitatif, metode deskriptif. Penelitian kualitatif disajikan dengan deskriptif. Subjek penelitian ini adalah guru kelas III B dan siswa kelas III B SDN Cikokol 1 Kota Tangerang. Objek penelitian ini adalah proses optimalisasi pembelajaran jarak jauh dengan teknologi informasi dan komunikasi. Teknik pengumpulan data dengan menggunakan teknik wawancara dan
\end{abstract}


observasi. Hasil penelitian ini menunjukkan bahwa dalam proses pembelajaran jarak jauh siswa sudah antusias selama mengikuti proses pembelajaran dengan menggunakan teknologi informasi dan komunikasi.Hal ini terlihat dari keaktifan mereka ketika sedang melaksanakan pembelajaran jarak jauh. Siswa juga lebih mudah menangkap dan memahami materi pelajaran sehingga siswa lebih tertarik dan lebih fokus dalam pembelajaran tersebut. Untuk optimalisasi teknologi informasi dan komunikasi dalam pembelajaran jarak jauh belum sepenuhnya optimal, karena selama proses pembelajaran jarak jauh ini, guru jadi sulit mengukur tingkat kepahaman siswa, karakter siswa dan penilaian akademiknya. Bahkan selama proses pembelajaran jarak jauh ini baru $80 \%$ siswa yang bisa mengakses video conference yang digunakan.

Kata Kunci: Optimal, Pembelajaran Jarak Jauh, Teknologi, Informasi, Komunikasi

\section{A. Pendahuluan}

\section{Covid-19}

(Coronavirus)

merupakan virus berbahaya yang ditemukan oleh World Health Organization (WHO) pada Desember 2019 di Wuhan, China. Virus ini menyerang banyak manusia dengan cara yang berbeda yang menganggu sistem pernafasan pada manusia. Pada kondisi saat ini seluruh dunia termasuk Indonesia sedang mengupaya agar warga tida mudah terserang virus ini karena virus ini menyerang sistem kekebalan tubuh manusia dari pandemi penyakit koronavirus 2019 (COVID-19). Kasus positif COVID-19 di Indonesia pertama kali dideteksi pada tanggal 2 Maret 2020, ketika dua orang terkonfirmasi tertular dari seorang warga negara Jepang. Pada tanggal 9 April, pandemi sudah menyebar ke
34

provinsi

dengan DKI Jakarta, Jawa

Timur dan Jawa Barat sebagai provinsi paling terpapar virus corona di Indonesia.

Ketidakstabilan timbul dari kekurangan-kekurangan dalam diri manusia atau kelompok sosial yang bersumber pada faktor-faktor ekonomis, biologis, biopsikologis, dan kebudayaan. Semakin hari permasalahan sosial ekonomi yang ditimbulkan akibat Covid-19 semakin terlihat nyata bagi masyarakat. Di lansir dari Puspensos Kementerian Sosial RI ada beberapa masalah yang terjadi akibat Covid-19 diantaranya, kelangkaan barang, disorganisasi dan disfungsi sosial, tindakan kriminal, melemahnya sektor pariwisata, angka kemiskinan dan pengangguran meningkat. Berbagai permasalahan sosial dan ekonomi 
terus muncul di tengah masyarakat. Tidak dapat dipungkiri jika Covid-19 telah hampir melumpuhkan kondisi sosial ekonomi masyarakat Indonesia, khususnya di beberapa daerah dengan tingkat penyebaran tertinggi seperti Jabodetabek. Sampai tanggal 8 Oktober 2020, Indonesia telah melaporkan 320.564 kasus positif menempati peringkat kedua terbanyak di Asia

Tenggara setelah Filipina dan kemungkinan akan terus bertambah. Akibat dari dampak Virus Corona, Pemerintah juga mengeluarkan kebijakan terkait Social distancing, PSBB, Lockdown. Oleh karena itu, masyarakat sangat bergantung pada teknologi yang ada untuk bisa mendapat informasi dan berkomunikasi dengan sesama.

Pada kondisi pandemi covid-19 seperti sekarang ini membuat teknologi menjadi keperluan dasar bagi setiap orang. Perkembangan teknologi yang semakin pesat mempermudah semua orang mendapatkan informasi darimana saja, serta untuk tetap terhubung dengan banyak orang. Tetapi tidak semua orang bisa menikmati kesempatan tersebut. Dikarenakan ketersediaan infrastruktur teknologi informasi dan komunikasi yang ada di Indonesia masih belum merata. Badan Pusat Statistik (BPS) menyatakan indeks pembangunan teknologi informasi dan komunikasi masih belum merata untuk bagian timur Indonesia. Lima provinsi dengan indeks pembangunan teknologi paling rendah yaitu Papua, Nusa Tenggara Timur, Sulawesi Barat, dan Maluku Utara. Berdasarkan pengukuran tersebut, maka diketahui bahwa indeks pembangunan teknologi informasi dan komunikasi tertinggi masih terdapat di DKI Jakarta dengan indeks sebesar 7,61, Yogyakarta 6,09; Kalimantan Timur 5,92; Bali 5,81; serta Kepulauan Riau 5,79. Sedangkan indeks pembangunan di bawah 4 untuk 8 provinsi, mayoritas terdapat di wilayah timur.

$$
\text { Pembangunan teknologi }
$$
informasi dan komunikasi yang masih belum merata ini menjadi salah satu penyebab penguasaan teknologi yang masih sangat rendah, terbukti dari indeks yang dipublikasikan lembaga-lembaga internasional. Misalnya International Telecomunication Union (ITU) pada 2017 menyebutkan indeks teknologi informasi dan komunikasi (TIK) 
Indonesia berada di posisi 111 dari 176 negara dengan indeks terbesar 4,34. Begitu juga indeks yang diterbitkan oleh World Economics Forum menyebutkan bahwa Indonesia ada pada rangking 80 dari 137 negara. Mengingat teknologi tidak lagi sekedar inovasi, pengetahuan, atau penerapan sains. Akan tetapi sudah menjadi faktor determinan bagi kemajuan peradaban penerus bangsa.

Dengan diberlakukannya sistem pembelajaran jarak jauh (daring) oleh pemerintah, banyak guru yang kurang dalam penguasaan teknologi atau gagap teknologi ini hanya memberikan tugas untuk dikerjakan di rumah agar siswa tidak menganggur. Menteri Pendidikan dan Kebudayaan (Mendikbud) Nadiem Makarim mendapat laporan dari sejumlah orang tua siswa lantaran ada beberapa guru yang hanya memberikan tugas berat, tapi tak disertai dengan bimbingan dalam pengerjaannya. Peninjauan KPAI tentang pelaksanaan proses pembelajaran jarak jauh di 20 provinsi dan 54 kabupaten/kota menyebut $73,2 \%$ siswa dari 1.700 responden, atau 1.244 siswa, merasa terbebani tugas dari para guru.
Sebanyak 1.323 siswa dari seluruh responden berkata sulit mengumpulkan tugas karena guru menuntut mereka mengerjakannya dalam waktu singkat.

Karena tugas yang berat dan tak disertai dengan bimbingan dalam pengerjaannya membuat proses pembelajaran jarak jauh menjadi kurang optimal. Pelaksanaan pembelajaran jarak jauh (daring) ini menuntut kesiapan bagi kedua belah pihak, baik itu dari fasilitator layanan pendidikan atau dari peserta didik sendiri. Teknologi menjadi hal yang terpenting dalam pembelajaran daring, teknologi tersebut diantaranya bisa berupa smartphone, laptop dan benda pendukung lainnya. Smartphone/gadget adalah hal yang paling umum digunakan peserta didik daripada laptop, karena lebih praktis dan banyak fitur canggihnya.

Akibatnya dengan terjadinya sistem pembelajaran jarak jauh ini peneliti memilih penelitian ini dengan maksud apakah proses guru dalam mengoptimalkan pembelajaran sistem jarak jauh denggan menggunakan teknologi dapat berjalan dengan baik dan benar? Dan apakah hasil dari pelaksanaan 
pembelajaran jarak jauh menggunakan teknologi informasi dan komunikasi kepada siswa dapat berjalan dengan baik? Tentunya akan terjadi kendala yang harus diperbaiki oleh pemerintah agar sistem pembelajaran pada saat pendemi ini dapat berjalan dengan sesuai dari tujuan pembelajaran. Tidak hanya itu saja, permasalahan guru yang kurang memahami teknologi dan informasi membuat kesulitan dalam menerapkan sistem pembelajaran pendemi, dengan kata lain dapat menghambat proses pembelajaran. Sehingga kasus seperti ini dapat menimbulkan kesulitan dalam pembelajaran.

\section{B. Metode Penelitian}

Penelitian ini menggunakan pendekatan kualitatif dimana peneliti menggunakan teknik wawancara sebagai metode dalam mengumpulkan data. Seperti halnya menurut Sugiyono (2014:9) metode penelitian kualitatif digunakan untuk meneliti yang bersifat subjek pada kondisi dimana para peneliti merupakan sebagai instrument kunci dalam teknik pengumpulan data yang dilakukan secara triangulasi (gabungan), analisis data dalam penelitian ini bersifat indukti dengan hasil penelitian kualitatif lebih menekankan pada makna dari pada generalisasi.

Observasi merupakan kegiatan dalam penelitian untuk mengetahui dan mengamati problem-problem yang dihadapi secara langsumg. Dalam penelitian ini peneliti hanya menggunakan pengamatan terus terang dan tersamar, alesannya peneliti memilih pengamatan terus terang dan tersamarkan, bahwasannya jarang sekali peneliti dapat mengamati subjek penelitian tanpa melibatkan orang lain yang menjadi sasaran dalam kegiatan penelitian. Dengan teknik ini peneliti dapat melihat dan merasakan secara langsung suasana dan kondisi subyek penelitian.

Menurut Sugiyono, wawancara merupakan pertemuan dua orang untuk bertukar informasi dan ide yang dilakukan dengan tanya jawab sehingga dapat menemukan informasi sesuai makna dan topik dalam pembahasan. Wawancara dilakukan dengan pertanyaanpertanyaan yang terbuka dengan memungkinkan informan memberikan jawaban yang diajukan secara luas. 
Wawancara sendiri merupakan salah satu teknik yang digunakan untuk mengumpulkan data atau informasi yang berhubungan dengan masalah penelitian di lapangan. Dengan adanya wawancara peneliti dapat mengetahui data dan informasi yang dibutuhkan.

Penelitian ini dilakukan dengan mengambil tempat di sekolah SDN 1 Cikokol Kota Tangerang tahun ajaran 2020-2021 yang melibatkan kelas III untuk dilakukan penelitian. Penelitian ini dilakukan dengan fokus masalah yaitu :

1. Melihat peran guru dalam mengembangkan potensi siswa melalui kegiatan pembelajaran jarak jauh (daring) di SDN Cikokol 1

2. Pembatasan materi hanya sampai pada sejauhmana peran guru dalam mengoptimalisasi pembelajaran jaral jauh dengan teknologi informasi dan komunikasi di SDN Cikokol 1

3. Kemampuan guru di SDN Cikokol 1 dalam mengembangkan potensi siswa melalui kegiatan pembelajaran jarak jauh (daring)

4. Dampak dari guru mengembangkan potensi siswa melalui kegiatan pembelajaran jarak jauh berbasis teknologi informasi dan komunikasi.

Penelitian ini dilakukan dengan menggunakan pendekatan kualitatif, metode deskriptif. Dalam kegiatan penelitian ini peneliti akan mencoba menggambarkan secara keseluruhan peristiwa maupun fenomena yang terjadi selama proses penelitian, terutama peristiwa yang berhubungan dengan tujuan selama proses penelitian.

\section{Hasil Penelitian dan Pembahasan}

Untuk mengoptimalisasi pembelajaran jarak jauh dengan teknologi informasi dan komunikasi telah diadakan penelitian pada tanggal 12 - 24 November 2020 dengan metode kualitatif. Pada penelitian kualitatif peneliti dituntut dapat menggali data berdasarkan apa yang diucapkkan, dirasakan atau dilakukan oleh sumber data. Pada penelitian kualitatif peneliti bukan sebagaimana seharusnya apa yang dipikirkan oleh peneliti tetapi berdasarkan sebagaimana adanya yang terjadi di lapangan, yang dialami, dirasakan, dan dipikirkan oleh sumber data. Dalam 
perkembangan kehidupan yang dinamis tuntutan teknologi informasi dan komunikasi menjadi garda terdepan terutama pada masa Pandemi Covid-19. Hal ini di optimalisasikan dalam bidang pendidikan melalui pembelajaran jarak jauh. Peran serta guru, peserta didik, orang tua, dan masyarakat harus saling bekerja sama mengelaborasikan tuntutan perkembangan zaman dan tantangan kehidupan. Pendidikan hadir menjadi sangat penting tanpa terhalang baik jarak maupun waktu, penelitian ini dilakukan untuk menjabarkan hal hal tersebut.

\section{Proses}

guru

dalam

mengoptimalisasi

pembelajaran jarak jauh melalui teknologi informasi \& komunikasi

Setiap pembelajaran baik itu yang dilakukan secara luar jaringan (luring) maupun dalam jaringan (daring), keduanya tetap menggunakan teknologi sebagai salah satu sarana penunjang pembelajaran.Pembelajaran jarak jauh dengan sistem dalam jaringan (daring) saat ini tengah dilaksanakan oleh seluruh satuan pendidikan salah satunya sekolah dasar.

Pembelajaran jarak jauh menggunakan teknologi sebagai sarana penunjang pembelajaran, maka setiap guru, peserta didik dan orang tua wali murid harus memahami penggunaan teknologi. Salah satunya adalah guru, sebagai seorang pendidik di era pembelajaran secara daring ini guru harus mampu mengoptimalisasi pembelajaran jarak jauh melalui teknologi informasi dan komunikasi. Guru harus mampu mengembangkan kemampuan dan pemahamannya terhadap teknologi agar pembelajaran tetap efektif dan menyenangkan.

Merujuk dari hasil penelitian, mengenai pembelajaran saat ini dimana sistem penerapan waktu bekerja berbeda dengan sebelum terjadinya pandemi yaitu muncul sistem tiga hari Work From Home (WFH) dan tiga hari di kantor, selain itu waktu kerja dari yang sebelumnya hanya terpaut dari jam 7 pagi sampai jam 2 siang untuk sekarang ini menjadi tidak menentu. Saat ini guru dituntut untuk bisa menggunakan teknologi, sehingga dalam pembelajaran jarak jauh ini agar 
menyenangkan penggunaan Power Point (PPT) sebagai media pembelajaran yang di design dengan semenarik mungkin agar siswa merasa tertarik dengan materi pembelajaran. Selain itu, penggunaan aplikasi zoom agar tetap terjadi tatap muka meskipun secara virtual pun juga digunakan untuk melakukan pembelajaran untuk menyampaikan materi belajar dari power point yang telah dipersiapkan.

Dalam pembelajaran jarak jauh rancangan perangkat pembelajaran pun tetap diperlukan dan tentunya terdapat beberapa perbedaan antara rancangan perangkat pembelajaran luring dan rancangan perangkat pembelajaran daring. Perbedaan tersebut terdapat pada langkahlangkah pembelajaran dimana penggunaan teknologi berperan penting, selain itu komponen lain didalam rancangan perangkat pembelajaran tetap sama. Kemudian, teknologi yang sangat diandalkan sebagai media dalam pembelajaran secara daring ini adalah smartphone, laptop, video pembelajaran dan beberapa platform daring seperti quizizz, website Tangerang Belajar, whatsapp serta google drive. Selain itu sesi tanya jawab pun juga dilakukan tetapi hanya jika pembelajaran sedang menggunakan zoom sedangkan dalam penerapan tugas, penggunaan aplikasi whatsapp berperan penting untuk menginformasikan terkait tugas-tugas yang harus dikerjakan dengan sistem pengumpulan yang berbeda-beda. Dimana jika pengumpulan tugas secara online maka bisa menggunakan google drive atau berupa foto yang dikirimkan melalui whatsapp tetapi jika pengumpulan tugas secara offline maka tugas tersebut langsung dikumpulkan disekolah melalui perwakilan wilayah dengan mematuhi protokol kesehatan.

Kegiatan pembelajaran jarak jauh juga membutuhkan strategi dalam penggunaan teknologi informasi dan komunikasi. Strategi penggunaan teknologi yang biasa digunakan sebagai alat komunikasi antara guru dan siswa adalah aplikasi whatsapp dan zoom. Sedangkan situs belajar yang sering kali digunakan adalah quizizz, socrative, dan google form. Dimana situs belajar tersebut digunakan untuk memberikan latihan soal kepada siswa. Pada intinya bahwa dalam pembelajaran jarak jauh seorang 
guru harus meningkatkan kemampuannya terkait penggunaan teknologi, sehingga pembelajaran pun menjadi efektif dan tidak membosankan hal itu adalah tantangan tersendiri bagi seorang guru untuk lebih kreatif dalam pembelajaran.

Dalam penentuan metode pengajaran yang digunakan selama pembelajaran jarak jauh untuk penyampaian materi ajar serta mencapai tujuan pembelajaran adalah metode ceramah dan demonstrasi hal ini disebabkan karena siswa dalam pembelajaran tersebut adalah siswa kelas rendah, sehingga guru hanya menerangkan terkait materi dan kemudian mendemonstrasikannya.

Didalam kegiatan pembelajaran jarak jauh ini pemerintah pun berkontribusi dengan memberikan bantuan berupa program untuk memfasilitasi siswa dalam pembelajaran jarak jauh dengan teknologi informasi dan komunikasi. Kemendikbud membuat relaksasi dana Bantuan Operasional Sekolah (BOS) berupa subsidi kuota internet, dimana satuan pendidikan diberi kewenangan mengalokasikan dana
BOS tersebut bagi guru dan siswa. Penyediannya siswa mendapatkan kuota internet sebanyak 35 GB/bulan sedangkan guru mendapatkaan 42 GB/bulan. Hal ini tentulah sangat membantu dalam mendukung dan memotivasi penyelenggaraan pembelajaran jarak jauh secara daring ini menjadi lebih efektif.

Berdasarkan hal yang telah dikemukakan diatas dapat diperkuat kembali dengan teori menurut Soerkatawi yang dikutip kembali oleh Yaumi, Muhammad (2018: 227) mengatakan bahwa penerapan pembelajaran jarak jauh dengan model blended learning dapat menghasilkan efisiensi yang sangat baik karena dirancang dengan kombinasi dari penerapan teknologi informasi e-learning, terdapat kegiatan face-to-face, dan praktik dunia nyata.

Selain itu, terdapat pula menurut Moore dan Anderson yang dikutip kembali oleh Yaumi, Muhammad (2018: 228-229) mengatakan pendidikan adalah semua bentuk pendidikan yang kebanyakan pembelajarannya dilakukan pada ruang yang terpisah dengan tempat pelaksanaan 
pembelajaran yang berdampak pada semua atau kebanyakan komunikasi antara pendidik dengan peserta didik melalui komunikasi teknologi. Di sini ditekankan bahwa pelaksanaan pembelajaran dengan menggunakan komunikasi yang berbasis teknologi baik dengan menggunakan teknologi sederhana maupun teknologi muktahir.

Ada pun menurut Newby dkk yang dikutip kembali oleh Yaumi, Muhammad (2018: 59) mengatakan bahwa metode pembelajaran adalah prosedur dan tindakan yang digunakan untuk membantu peserta didik mencapai tujuan pembelajaran.

Kemudian menurut Smaldino, Lowther, dan Russell yang dikutip kembali oleh Yaumin, Muhammad (2018: 59) mengatakan bahwa strategi pembelajaran adalah prosedur dipilih untuk membantu peserta didik mencapai tujuan atau menginternalisasi konten. Strategi pembelajaran berkaitan dengan media dan teknologi bahkan dipandang menjadi bagian yang integral dalam penerapan strategi.

\section{Kemampuan guru dalam} mengoptimalisasi teknologi
informasi \& komunikasi pada siswa melalui pembelajaran jarak jauh

Dilakukannya observasi ini untuk mengetahui sejauh mana kemampuan guru dalam mengoptimalisasi teknologi, informasi dan komunikasi indikatornya yaitu : (1) Pemahaman guru dalam menggunakan teknologi informasi dan komunikasi untuk pembelajaran. (2) Penerapan guru dalam mengaplikasikan teknologi informasi dan komunikasi untuk pembelajaran jarak jauh. (3) Keterampilan guru dalam Menciptakan kegiatan pembelajaran yang menarik, serta mengedukasi peserta didik dengan teknologi informasi \& komunikasi. (4) Mengevaluasi kegiatan pembelajaran jarak jauh berbasis teknologi informasi dan komunikasi. Seperti yang sudah kita ketahui bahwa dalam indikator pertama yang harus dikuasai oleh seorang guru dalam mengoptimalisasi teknologi informasi dan komunikasi adalah pemahaman guru dalam menggunakan teknologi informasi dan komunikasi untuk pembelajaran. Menjadi seorang guru sebelum memulai pembelajaran dikelas harus mempersiapkan alat dan bahan sebelum memulai pembelajaran daring, memandu 
untuk menggunakan aplikasi pembelajaran kepada peserta didik agar kegiatan belajar sudah tersusun dan proses pembelajaran berjalan dengan lancar dan sistematis sesuai dengan apa yang diharapkan.

Dalam aspek kemampuan ini bisa dikatakan Ibu lin sudah paham dalam menggunakan teknologi informasi dan komunikasi untuk pembelajaran jarak jauh. Hal ini dikarenakan setiap peneliti melakukan pengamatan di kelas 3 , Ibu lin sudah paham dalam menyiapkan alat dan bahan sebelum melakukan proses pembelajaran, Ibu lin juga memandu siswa untuk menggunakan aplikasi pembelajaran yang digunakan. Selain itu lbu lin juga sudah mempersipkan materi yang akan disampaikan dengan menggunakan Power Point. Selama pembelajaran jarak jauh ini Ibu lin selalu mengikuti pelatihan -pelatihan online yang disediakan oleh Pemerintah. Jadi, Bu lin sudah menguasai beberapa aplikasi atau web yang digunakan untuk mengevaluasi peserta didik seperti Google form, kahoot, quizizz, dan socrative.
Indikator kedua yaitu penerapan guru dalam mengoptimalisasikan teknologi informasi dan komunikasi untuk pembelajaran jarak jauh. Dalam melakukan pengamatan peneliti melihat Ibu lin sudah membuat media pembelajaran yang menarik dan kreatif seperti Power Point yang ada gambar - gambar nya sehingga terlihat menarik dan tidak membosankan. Ibu lin juga membagikan bahan ajar yang digunakan untuk pembelajaran jarak jauh dalam format digital seperti menggunakan video pembelajaran yang di unggah di YouTube. Ibu lin juga menggunakan Situs Tangerang Belajar yang di sediakan oleh pemerintah Kota Tangerang dimana dalam situs tersebut banyak berisi tentang video - video pembelajaran yang dibuat oleh Guru - Guru pilihan se Kota Tangerang. Power Point serta Video pembelajaran yang disampaikan kepada peserta didik dibuat bagus sedemikian rupa agar terlihat menarik sehingga siswa tertarik untuk mengikuti pelajaran tersebut.

Seperti yang dikatakan oleh Moch Uzer Usman (2013:27) kondisi belajar mengajar yang efektif adalah adanya minat dan perhatian siswa 
dalam belajar. Minat merupakan suatu sifat yang relatif menetap pada diri seseorang. Minat sangat besar pengaruhnya terhadap belajar sebab dengan minat seseorang akan melakukan sesuatu yang diminatinya. Keterlibatan siswa dalam belajar erat kaitannya dengan sifat - sifat murid, baik yang bersifat kognitif seperti kecerdasan dan bakat maupun yang bersifat afektif seperti motivasi, rasa percaya diri, dan minatnya.

$\begin{array}{ccc}\text { Indikator } & \text { ketiga } & \text { yaitu } \\ \text { keterampilan } & \text { guru } & \text { dalam }\end{array}$

menciptakan kegiatan pembelajaran.

Selama melakukan pengamatan, peneliti melihat Ibu lin sangat terampil dalam menciptakan kegiatan pembelajaran. Dalam proses kegiatan pembelajaran, Ibu lin menjelaskan materi sesuai dengan bahan ajar, menggunakan metode ceramah dan demostrasi yang membuat proses pembelajaran menjadi kondusif. Dalam menciptakan suasana belajar yang kondusif Ibu lin juga membuat peraturan kepada peserta didik untuk menyalakan mikrofon jika ingin bertanya atau menjawab pertanyaan.

Berdasarkan hal yang dikemukakan diatas, diperkuat kembali oleh teori menurut Sholeh Hidayat (2017:8) dalam salah satu bukunya menyebutkan bahwa Guru sebagai organisator dikelas yakni berperan mengatur dan menata ruang kelas dan siswa sehingga kelas lebih kondusif, dinamis, dan interaktif. Kelas yang kondusif adalah kelas yang dapat mengarahkan dan membimbing siswa belajar dalam situasi belajar yang tidak membosankan. Sebagai organisator, guru bertugas untuk mengatur dan menyiapkan perancangan pembelajaran, melaksanakan prosedur pembelajaran, mengevaluasi dan melaksanakan tindak lanjut.

Indikator terakhir yaitu mengevaluasi kegiatan pembelajaran jarak jauh berbasis teknologi informasi dan komunikasi. Selama melakukan pengamatan, peneliti melihat $\mathrm{Bu}$ lin sudah melaksanakan proses evaluasi kepada peserta didik dengan berbasis teknologi informasi dan komunikasi. Dalam mengevaluasi peserta didik, Ibu lin memberikan latihan soal melalui link Google Form, latihan soal menggunakan Quizizz, Kahoot, dan Socrative. Ibu lin juga menanyakan pendapat kepada peserta didik 
mengenai tingkat kesulitan dan kemudahan pada saat menggunakan aplikasi atau web selama evaluasi dalam pembelajaran jarak jauh ini. Ibu lin juga memberikan pilihan kepada peserta didik mau menggunakan aplikasi atau web yang mana jika ingin mengadakan evaluasi.

Berdasarkan hal diatas diperkuat lagi dengan teori menurut Sholeh Hidayat (2017:11) dalam salah satu bukunya menyebutkan guru sebagai evaluator. Evaluasi atau penilaian merupakan salah satu aspek pembelajaran yang kompleks karena melibatkan berbagai faktor. Tidak ada pembelajaran tanpa penilaian karena penilaian merupakan proses untuk menentukan tingkat pencapaian tujuan pembelajaran atau kompetensi oleh siswa. Sebagai suatu proses, penilaian dilaksanakan dengan jenis dan teknik yang sesuai baik berupa tes maupun non tes. Penilaian berbentuk tes meliputi penilaian formatif dan penilaian sumatuf, sedangkan penilaian nontes berupa pengamatan terhadap perilaku siswa, wawancara, sosiometri, dan sebagainya. Teknik dan bentuk apapun yang dipilih dan digunakan, penilaian harus dilakukan dengan prosedur yang jelas yang meliputi tahap perencanaan atau persiapan, pelaksanaan dan tindak lanjut.

\section{Dampak pembelajaran jarak jauh dengan teknologi informasi \& komunikasi}

Didalam kegiatan pembelajaran sudah pasti akan menghasilkan sebuah dampak atau hasil, baik itu negatif atau positif atau baik itu dalam pembelajaran luar jaringan (luring) maupun dalam jaringan (daring). Dalam pembelajaran jarak jauh secara daring ini tentu akan memiliki dampak terutama kepada siswa. Karena dalam pembelajaran daring ini siswa pun harus pandai menggunakan teknologi informasi dan komunikasi dalam pembelajaran jarak jauh.

Merujuk kepada hasil penelitian didalam pembelajaran jarak jauh guru menggunakan beberapa aplikasi dan platform daring dalam proses mengajar dan sudah tentu guru akan membimbing siswanya agar dapat menguasai penggunaan aplikasi dan platform daring tersebut. Sehingga, pada saat pembelajaran berlangsung 
siswa dapat mengikuti dengan baik pembelajaran melalui aplikasi seperti zoom serta mengerti tata cara dari penggunaan aplikasi tersebut. Oleh karena itu, dapat diketahui bahwa siswa sudah mampu dan dapat mengaplikasikan penggunaan teknologi informasi dan komunikasi didalam pembelajaran jarak jauh ini.

Tidak cukup dengan siswa mampu dalam penggunaan teknologi untuk pembelajaran, keaktifan siswa dalam proses pembelajaran jarak jauh jauh secara daring ini pun juga menjadi faktor penting dalam kegiatan pembelajaran. Siswa dituntut untuk berperan aktif dalam mengikuti proses pembelajaran dikelas. Untuk membuat siswa berperan aktif ketika pembelajaran, peran guru sangat penting untuk menstimulus siswa atau memberikan pembelajaran daring yang menarik sehingga siswa antusias dalam menerima pembelajaran yang diberikan oleh guru. Guru mengatakan bahwa siswa aktif dalam pembelajaran dikarenakan siswa terlibat langsung saat proses pembelajaran, dimana keaktifan siswa dapat terlihat ketika mampu untuk menjawab setiap pertanyaan yang diajukan oleh guru, ataupun bertanya mengenai hal yang kurang atau tidak mereka pahami. Selain itu, siswa pun aktif dalam membaca materi yang telah diberikan oleh guru dan aktif dalam berinteraksi secara baik dengan guru maupun dengan teman sebayanya walaupun secara daring. Memang tidak memungkinkan bahwa semua siswa dapat berperan aktif dalam pembelajaran ada pun siswa yang tidak begitu aktif dalam pembelajaran.

Dalam kegiatan pembelajaran jarak jauh ini guru dan pihak sekolah memiliki tantangan tersendiri supaya siswa yang diajar tetap termotivasi untuk belajar karena dengan keadaan seperti ini memungkinkan untuk siswa merasa jenuh dan bosan terhadap pembelajaran. Oleh karena itu, pemerintah memberikan paket pembelajaran yang memungkinkan siswa dapat mengakses paket pembelajaran tersebut. Selain itu, siswa menjadi sangat antusias dalam belajar ketika media pembelajaran yang dibuat oleh guru sangat menarik. Dimana didalam media itu terdapat beberapa gambar dan karakter animasi yang membuat siswa dapat melihat gambaran konkret dari materi yang dipelajarinya. Hal itu membuat siswa 
menjadi senang dan termotivasi lebih untuk belajar.

Berdasarkan hal yang telah dikemukakan di atas dapat diperkuat kembali menurut Muali yang dikutip kembali dalam jurnal Pendidikan Agama Islam Edureligia, Septantiningtiyas, Niken (2018: 2) hasil penelitian Muali, dkk yang menunjukkan bahwa pembelajaran yang berbasis teknologi sangat membantu siswa dalam memahami pembelajaran secara lebih baik. Kemudian menurut Budiana yang dikutip kembali dalam jurnal Pendidikan Agama Islam Edureligia, Septantiningtiyas, Niken (2018: 2) mengatakan bahwa secara umum ada dua faktor yang mempengaruhi hasil belajar yaitu faktor internal dan faktor eksternal. Minat belajar termasuk dalam faktor internal memiliki hubungan erat terhadap hasil belajar. Selain itu, menurut Budiman yang dikutip kembali dalam Jurnal Pendidikan Agama Islam Edureligia, Septantiningtiyas, Niken mengatakan bahwa hal ini berarti selain dampak positif terhadap hasil belajar, penggunaan teknologi dalam pembelajaran dapat berdampak positif pada minat belajar.

\section{Kesimpulan}

Berdasarkan pembahasan teori ahli dan pemaparan hasil penelitian yang telah peneliti lakukan yaitu untuk mengetahui bagaimana proses mengoptimalisasi pembelajaran jarak jauh dengan teknologi informasi dan komunakasi, dapat disimpulkan bahwa antara teori ahli dengan yang terjadi di lapangan khususnya di SDN Cikokol 1 yang kami teliti memperoleh data yang hampir sama. Guru sebagai tenaga pendidik melalui kegiatan pembelajaran di kelas III sudah tergolong cukup baik. Hal ini ditandai dengan siswa yang aktif dalam mengikuti kegiatan pembelajaran secara daring. Namun yang menjadi kekurangan dalam hal tersebut adalah masih ada siswa yang belum bisa sepenuhnya mengikuti kegiatan pembelajaran daring dikarenakan beberapa kendala.

Kemudian untuk proses guru dalam mengoptimalisasi pembelajaran jarak jauh secara daring. Beliau sudah mengusahakan yang terbaik mulai dari selalu mengikuti latihan untuk pembelajaran daring yang disediakan oleh dinas kota, belajar secara otodidak untuk 
membuat media pembelajaran yang menarik bagi siswa, sampai berbagi ilmu pada tenaga pendidik yang lain. Ibu lin juga membimbing siswa yang masih belum paham, sampai paham.

Setelah itu kemampuan guru dalam mengoptimalisasi pembelajran jarak jauh secara daring, peneliti menyimpulkan bahwa Ibu lin sudah cukup mampu mengoptimalisasi pembelajaran siswa secara daring. Beliau juga mampu menjalin interaksi dengan siswa, serta bisa mengaplikasikan pembelajaran daring dengan beberapa aplikasi dan platform tertentu mulai dari pembelajaran melalui Whatsapp, Zoom Meeting, Google form, Quizizz, dan sebagainya. Beliau juga membuat beberapa media pembelajaran seperti PowerPoint dan Video pembelajaran supaya siswa memiliki variasi media dalam belajarnya agar tidak cepat bosan dan tetap semangat walaupun pembelajaran di laksanakan dirumah.

Selanjutnya hasil dari pelaksanaan pembelajaran jarak jauh melalui teknologi informasi \& komunikasi, peneliti menyimpulkan bahwa kinerja lbu lin dalam meningkatkan pembelajaran secara daring memberikan pengaruh positif pada siswa di kelas III. Sehingga siswa menjadi lebih bisa mengaplikasikan teknologi informasi dan komunikasi dalam pembelajaran ini. Dimana hal itu membuat Siswa juga menjadi lebih aktif dalam kegiatan pembelajaran daring ini. Serta Siswa menjadi lebih bersemangat dan antusias dalam belajar.

\section{DAFTAR PUSTAKA}

Uzer Usman, Moch. (2013). Menjadi Guru Profesional. Bandung : PT REMAJA ROSDAKARYA

Yaumi, Muhammad. (2018). MEDIA \& TEKNOLOGI PEMBELAJARAN. Jakarta: Prenadamedia Group

Hidayat, Sholeh.

(2017).

Pengembangan Guru

Profesional. Bandung : PT REMAJA ROSDAKARYA

Septantiningtyas, Niken. (2018). Pengaruh Pembelajaran Jarak Jauh dengan Aplikasi Google Class Terhadap Hasil Belajar Mahasiswa. Jurnal Pendidikan Agama Islam Edureligia. 2(2): 2. 